\title{
Evaluasi Kinerja Gedung Menggunakan Base Isolation Tipe High Damping Rubber Bearing (HDRB) Pada Modifikasi Gedung J-Tos Jogjakarta Dengan Perencanaan Analisis Pushover
}

\author{
Wiki Andrian, Faimun, dan Endah Wahyuni \\ Departemen Teknik Sipil, Fakultas Teknik Sipil dan Perencanaan, Institut Teknologi Sepuluh \\ Nopember (ITS) \\ E-mail: faimun@ce.its.ac.id, endah@ce.its.ac.id
}

\begin{abstract}
Abstrak-Base isolation merupakan salah satu alat peredam gempa yang banyak digunakan pada dunia konstruksi, salah satunya pada Gedung J-Tos Jogjakarta. Pada studi ini akan dianalisis kinerja gedung tersebut dengan melakukan perencanaan gempa pada daerah gempa kecil kemudian hasil analisys tersebut digunakan untuk mendesain bagunan pada daerah gempa kuat dengan menambahkan base isolation tipe high damping rubber bearing (HDRB) pada dasar bangunan selanjutnya dilakukan analisis pushover. Gedung dimodifikasi pada jumlah lantainya yang sebelumnya 6 lantai menjadi 8 lantai. Dari hasil perhitungan analisis struktur. Displacement pada gedung yang menggunakan HDRB lebih besar dari pada gedung yang menggunakan sistem fixed-base yaitu akibat beban gempa dinamik displacement meningkat $66,97 \%$ untuk arah $x$ dan $57,53 \%$ untuk arah $y$, Simpangan antar lantai $(\Delta)$ pada gedung yang menggunakan HDRB lebih kecil dari pada gedung yang menggunakan sistem fixed-base yaitu akibat beban gempa dinamik $\Delta_{\text {rata-rata }}$ tereduksi $82,52 \%$ untuk arah $\mathrm{x}$ dan $\mathbf{7 8 , 0 8 \%}$ untuk arah y, Dari hasil analisis pushover, level kinerja gedung denganisolasi berdasarkan ATC-40, FEMA 356 dan FEMA 400 adalah B (Operational).
\end{abstract}

Kata Kunci-Analisis pushover, base isolator, high damping rubber bearing, level kinerja struktur.

\section{PENDAHULUAN}

G EDUNG J-Tos Jogjakarta merupakan gedung 6 lantai, dibangun sebagai tempat pusat perbelanjaan. Dengan mempertimbangkan aspek-aspek gempa bumi yang terjadi pada gedung dan untuk menghindari kerusakan struktur secara konvensional maka gedung ini dilengkapi dengan seismic device salah satunya yaitu base isolation. Pada studi ini akan dianalisis kinerja gedung tersebut dengan melakukan perencanaan gempa pada daerah gempa kecil kemudian hasil analisys tersebut digunakan untuk mendesain bagunan pada daerah gempa kuat dengan menambahkan base isolation.

Konsep dari base isolation yaitu memisahkan struktur atas dengan struktur bawah yang bekerja dengan menjaga struktur diatasnya sebagai satu kesatuan karena base isolator bersifat elastis maka arah getaran gempa yang terjadi secara acak hanya akan mempengaruhi base isolator, sedangkan struktur diatasnya akan bergetar atau bergerak sebagai satu kesatuan struktur [1]. Ada banyak sistem isolasi yang digunakan pada base isolasator, khusus pada gedung yang akan direncanakan ini digunakan tipe High Damping Rubber Bearing (HDRB) [2][3].

Sistem High Dumper Rubber Bearing (HDRB) menggunakan karet untuk mengurangi getaran gempa sedangkan lempengen baja yang terdapat pada lapisan berfungsi untuk menambah kekakuan bantalan karet sehingga defleksi dan deformasi bangunan saat bertumpu diatas bantalan karet tidak besar [2].

Dalam analisis, kesulitan yang mungkin didapati ialah merencanakan struktur gedung yang kuat dan stabil terhadap beban lateral terutama beban gempa. Maka dari itu diperlukan analisis lebih lanjut mengenai pengaruh beban gempa terhadap perilaku struktur bangunan gedung yang dengan dan tanpa menggunakan base isolation. Sehingga diharapkan dalam perencanaan struktur gedung, dapat dihasilkan disain optimum elemen struktur dan pengguanaan base isolation yang kuat dan stabil dalam menghadapi beban lateral yang besar dengan menggunakan sistem base isolation. Serta diharapkan dapat mengetahui prilaku keruntuhan terhadap beban gempa yang terjadi dengan melakukan analisis statik nonlinear pushover pada bangunan tersebut.

Analisis pushover adalah suatu cara untuk menganalisis struktur dengan beban statik tertentu dalam arah lateral yang diaplikasikan sepanjang ketinggian struktur dan ditingkatkan sampai struktur mencapai simpangan target [4]. Hasil analisis pushover adalah kurva yang menunjukkan hubungan antara Base Shear dengan simpangan lantai atap maksimum ( Top Floor Displacement ) seperti ditunjukkan pada gambar 1 . Hubungan tersebut kemudian dipetakan menjadi suatu kurva yang dinamakan Kurva Kapasitas struktur [5]. 

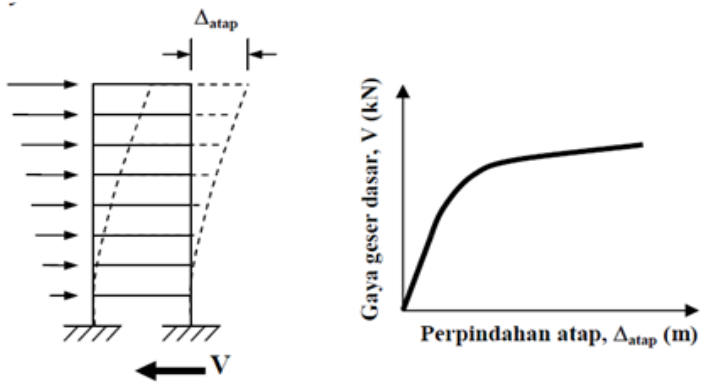

Gambar 1. Kurva Kapasitas.

Apabila kurva kapasitas berpotongan dengan kurva respon spectrum maka akan didapat performance point. Pada Performance Point dapat diperoleh informasi mengenai periode bangunan dan redaman efektif akibat perubahan kekakuan struktur setelah terjadi sendi plastis. Berdasarkan informasi tersebut respons-respons struktur lainnya seperti nilai simpangan tingkat dan posisi sendi plastis dapat diketahui [4][6].

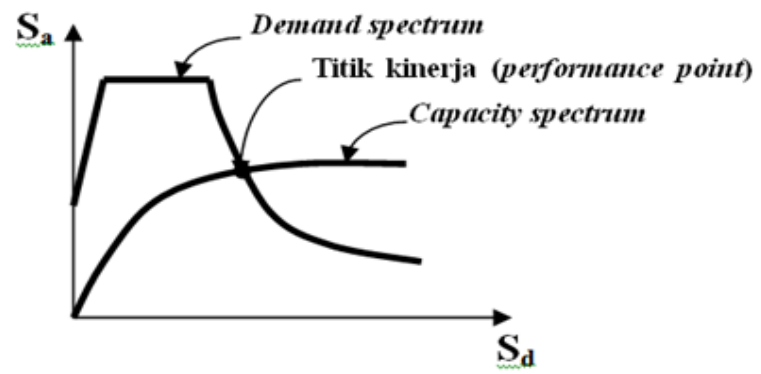

Gambar 2. Performance Point pada Capacity Spectrum Method.

Sasaran kinerja terdiri dari kejadian gempa rencana yang ditentukan dan taraf kerusakan yang diijinkan atau level kinerja (performance level) dari bangunan terhadap kejadian gempa tersebut, mengacu pada FEMA-273 yang menjadi acuan klasik bagi perencanaan berbasis kinerja maka kategori level kinerja struktur dapat dilihat berdasarkan gambar dibawah ini

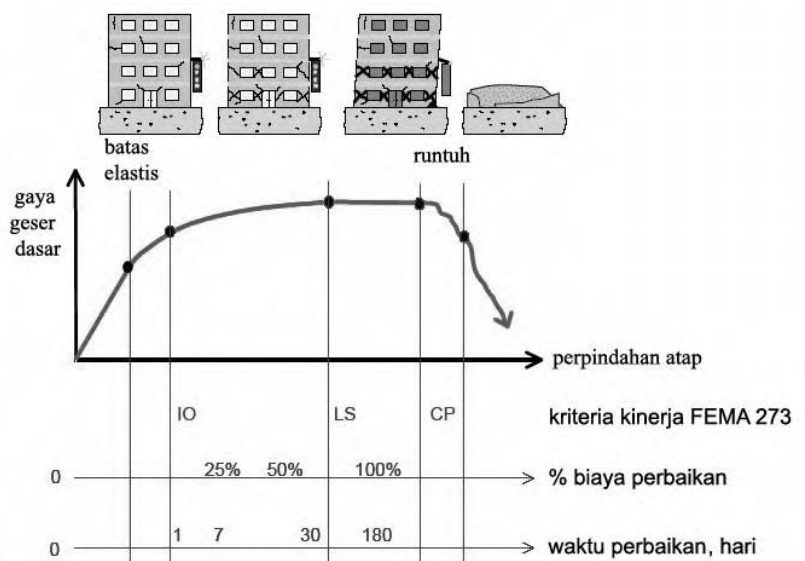

Gambar 3. Kurva Perfomance Levels (Tingkat Kinerja) dari Hubungan GayaPerpindahan Suatu Bangunan [7].

\section{METODOLOGI}

Langkah awal dalam studi ini adalah mengumpulkan datadata umum bangunan, kemudian mencari literatur dan peraturan tentang sistem isolasi seperti buku Base Isolation Of Structure by Trevor E Kelly atau buku Design Of seismic
Isolated Structure by James M Kelly dan untuk tata cara perencanaan struktur beton bertulang gedung mengacu pada SNI 03-2847-2013, untuk pembebanan mengacu pada SNI 1727-2013, untuk perencanaan ketahanan gempa untuk struktur bangunan gedung mengacu pada SNI 03-1726-2012. Lalu dilakukan analisis struktur fixed base dan base isolation dimulai dari preliminary design (balok utama, kolom, pelat, balok sekunder). Langkah berikutnya, permodelan 3D struktur bangunan fixed base kedalam program analisis struktur. Kemudian dilakukan analisis pembebanan yang bekerja pada gedung yang ditinjau (mati, hidup, gempa) dan inputkan beban tersebut kedalam program analisis struktur. Langkah selanjutnya yaitu kontrol desain yang telah direncanakan sebelumnya seperti: kontrol simpngan antar lantai, kontrol gaya geser static dan dinamik, dll. Apabila salah satu control desain tidak memenuhi maka dilakukan preliminary design ulang kembali. Apabila semua kontrol desain telah memenuhi maka dilanjutkan dengan analisis pushover dengan bantuan program analisis struktur. Dari hasil analisis pushover didapatkan data berupa batas maksimum displacement dan gaya geser maksimum yang mampu diberikan pada gedung . Langkah selanjutnya mengevaluasi level kinerja struktur apakah masih dalam batas aman atau tidak sesuai dengan peraturan yang ada seperti ATC-40, FEMA 356 dan FEMA 440. Langkah selanjutnya yaitu analisis struktur pada sistem base isolator dimulai dengan menghitung parameter yang berkaitan dengan kekakuan base isolation, data analisis struktur yang dibutuhkan diambil dari analisis struktur sebelumnya (fixed base). Kemudian dilakukan kontrol desain seperti langkah sebelumnya serta analisis pushover. Langkah selanjutnya yaitu membandingkan hasil analisis struktur pada fixed base dan isolation system sehingga didapat suatu kesimpulan terhadap penggunaan base isolator tipe HDRB pada gedung yang ditinjau.

\section{HASIL DAN PEMBAHASAN}

A. Data Umum Bangunan

$\begin{array}{ll}\text { - Fungsi } & \text { : Pusat Perbelanjaan } \\ \text { - Lokasi } & \text { : Jogjakarta } \\ \text { - Panjang Bangunan } & : 60 \mathrm{~m} \\ \text { - Lebar bangunan } & : 42 \mathrm{~m} \\ \text { - Tinggi bangunan } & : 34 \mathrm{~m} \text { (8 lantai) } \\ \text { - Zona Gempa } & : \text { Areal Jogjakarta } \\ \text { - Mutu beton (f'c) } & : 35 \mathrm{MPa} \text { (kolom) } \\ & 30 \mathrm{MPa} \text { (balok dan pelat) } \\ \text { - Mutu baja (f'y) } & : 400 \mathrm{MPa} \text { (BJTD U4) }\end{array}$

B. Preliminary Struktur Primer

- Kolom Utama: 65/65 cm

- Balok Utama: 40/60 cm

- Balok BG (Ground Beam): 40/80 cm

\section{Analisis Struktur Isolasi}

Analisis Isolation structure dimulai dari analisis fixed based, mendapatkan reaksi dan periode struktur kondisi terjepit, untuk perhitungan kebutuhan dimensi Base isolator HDRB rencana. Langkah-langkah nya yaitu:

- Menghitung berat bangunan, dari hasil analisis struktur 
didapat $\mathrm{Wt}=213599,53 \mathrm{kN}$

- Menentukan periode rencana $\left(T_{D}\right)$ untuk dimensi HDRB berdasarkan SNI 1726:2012 pasal 12.4, $\mathrm{T}_{\mathrm{D}}=3 \mathrm{x} \mathrm{T}$ fundamental fixed base $=3 \times 2,91=8,73$ detik

- Menghitung kekakuan isolasi rencana, dengan asumsi spesifikasi awal berdasarkan Brosur Base Isolator yang akan digunakan, untuk studi ini menggunakan brosur dari Bridgestone.

- Modulus shear $(\mathrm{G})=0,620 \mathrm{~N} / \mathrm{mm}^{2}=0,620 \mathrm{MN} / \mathrm{m}^{2}$

- Ketebalan rubber $(\operatorname{tr})=200 \mathrm{~mm}$

- Reaksi (titik 20) (m) $=18486,52 \mathrm{kN}=18,48652 \mathrm{MN}$

- Nilai kekakuan horizontal base isolation :

$K_{H}^{1}=\frac{m \times\left(\frac{2 \pi}{T}\right)^{2}}{\text { Pj.betang }}=\frac{18,48652 \times\left(\frac{2 \pi}{8,73}\right)^{2}}{6}=1.59 \mathrm{MN} / \mathrm{m}$

- Nilai luasan rubber

$K_{H}^{1}=\frac{G_{t} \times A}{t r} \rightarrow A=\frac{K_{H} \times t r}{G_{t}}=\frac{1.59 \times 0.2}{0.62}=0.514 \mathrm{~m}^{2}$

Sehingga diperoleh diameter rubber :

$$
A=\frac{1}{4} \times \pi \times D^{2} \rightarrow D=\sqrt{\frac{(4 A)}{\pi}}=0.809 \mathrm{~m}
$$

Dari brosure yang digunakan didapat hasil perhitungan dimensi HDRB yaitu : HH80X6R (Interior) dan HH65X6R (Eksterior).

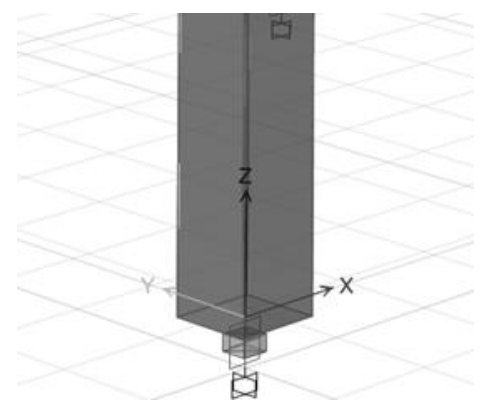

Gambar 4. Permodelan struktur menggunakan HDRB.

\section{Analisis Seismic Isolatoin berdasarkan AASHTO}

Untuk sistem isolasi dimana redaman efektif dinyatakan sebagai persentase, AASHTO menyisaratkan adanya konversi nilai redaman efektif ke priode efektif sutruktur isolator.

Tabel 1.

Koefisien redaman struktur Isolasi berdasarkan AASTHO [8].

\begin{tabular}{|l|l|l|l|l|l|l|l|}
\hline \multicolumn{7}{c|}{ Damping (Percentage of Critical)* } \\
\cline { 2 - 8 } & $\leq 2$ & 5 & 10 & 20 & 30 & 40 & 50 \\
\hline$B$ & 0.8 & 1.0 & 1.2 & 1.5 & 1.7 & 1.9 & 2.0 \\
\hline
\end{tabular}

Redaman effevtive Base Isolator yang digunakan adalah 24 sehingga didapatkan nilai $\mathrm{B}=1.58$.

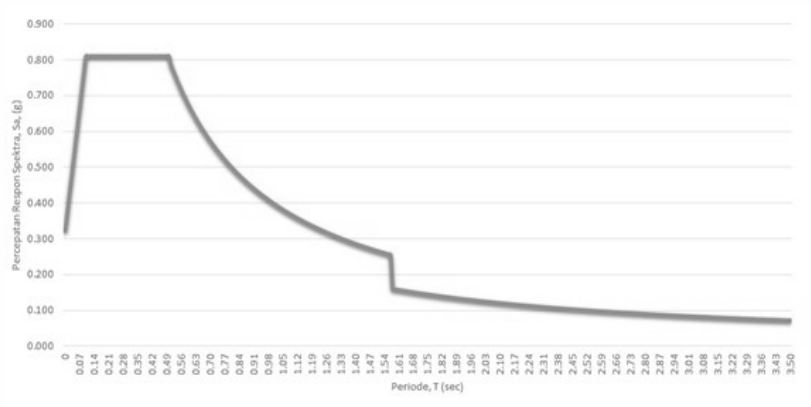

Gambar 5. Respons Spektrum Base Isolator dengan redaman $24 \%$.

\section{E. Perbandingan Displacement dan Simpangan Antar Lantai}

Defleksi pusat massa di Tingkat $x(\delta x)$ harus ditentukan sesuai dengan persamaan (SNI 1726-2012 Persamaan 7.8-14).

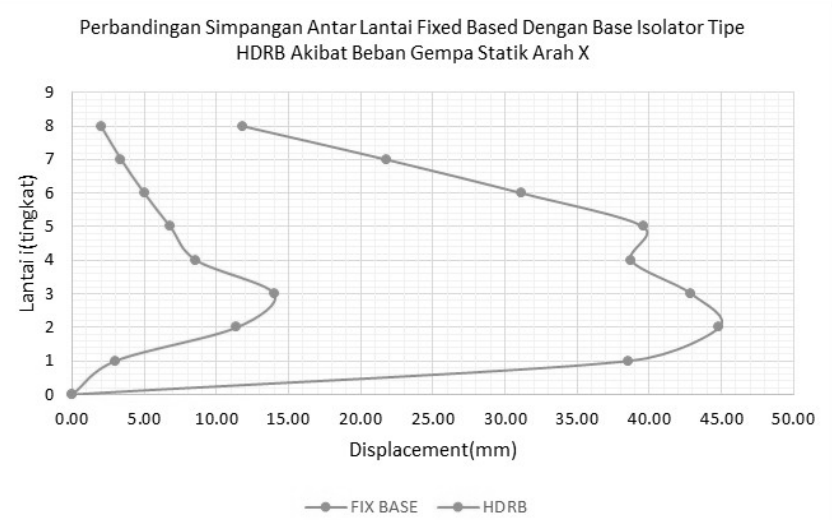

Gambar 6. Perbandingan displacement fixed based dengan HDRB akibat gempa respon spectrum arah $\mathrm{x}$.

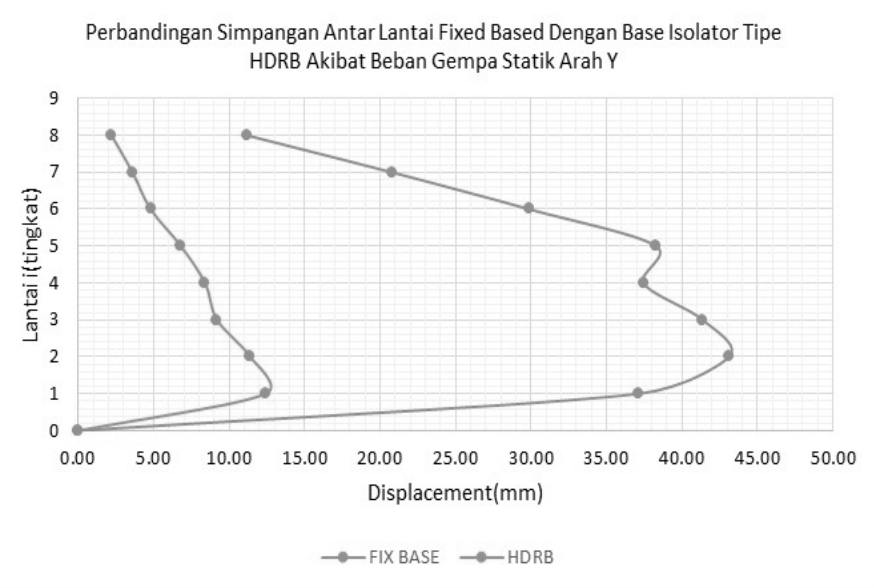

Gambar 7. Perbandingan displacement fixed based dengan HDRB akibat gempa respon spectrum arah y. 


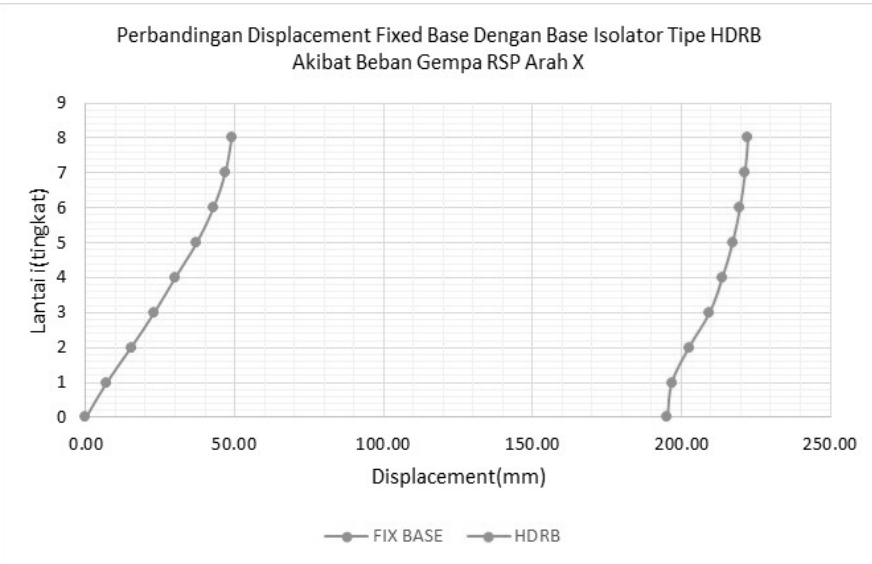

Gambar 8. Perbandingan simpangan $(\Delta)$ fixed based dengan HDRB akibat gempa respon spectrum arah $\mathrm{x}$.

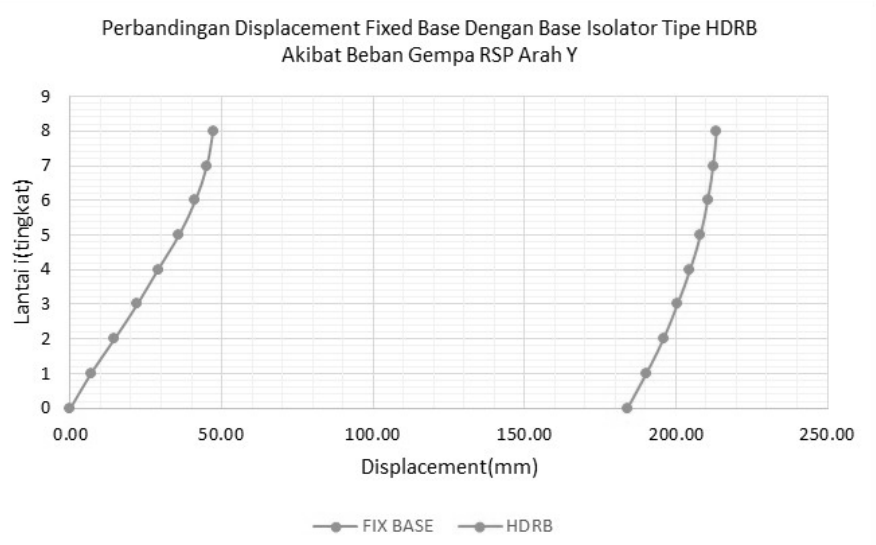

Gambar 9. Perbandingan simpangan $(\Delta)$ fixed based dengan $H D R B$ akibat gempa respon spectrum arah y.

Tabel 2.

Perbandingan displacement gedung yang menggunakan HDRB dengan fix based akibat gempa dinamik

\begin{tabular}{|c|c|c|c|}
\hline \multicolumn{4}{|c|}{ Gempa Dinamik } \\
\hline \multicolumn{3}{|c|}{$\operatorname{Arah} \mathrm{X}$} & \multirow{2}{*}{$\begin{array}{l}\text { Peningkatan } \\
\text { displacement }\end{array}$} \\
\hline & Sistem Isolasi & Fixed base & \\
\hline Displacement Lantai Atas (DA) (mm) & 222.40 & 133.20 & $66.97 \%$ \\
\hline Displacement Isolator (DB) $(\mathrm{mm})$ & 195.30 & & \\
\hline Selisih displacement : DA-DB & 27.1 & & \\
\hline Reduksi displacement & \multicolumn{2}{|c|}{$79.65 \%$} & \\
\hline \multicolumn{3}{|c|}{$\operatorname{Arah} \mathrm{Y}$} & \multirow{2}{*}{$\begin{array}{l}\text { Peningkatan } \\
\text { displacement }\end{array}$} \\
\hline & Sistem Isolasi & Fixed base & \\
\hline Displacement Lantai Atas (DA) (mm) & 213.40 & 135.47 & $57.53 \%$ \\
\hline Displacement Isolator (DB) (mm) & 184 & & \\
\hline Selisih dispalcement : DA-DB & 29.4 & & \\
\hline Reduksi displacement & & \\
\hline
\end{tabular}

Dari tabel dan grafik perbandingan di atas, displacement base isolator (HDRB) lebih besar daripada fix based. Hal ini dikarenakan deformasi dari isolator itu sendiri sehingga menyebabkan meningkatnya displacement dan berdampak pada lantai - lantai di atasnya.

Tabel 3.

Perbandingan nilai reduksi simpangan rata-rata antar lantai pada gedung yang menggunakan HDRB dengan fix based

\begin{tabular}{|l|r|}
\hline \multicolumn{1}{|c|}{ Beban Gempa Dinamik } & \multicolumn{1}{l|}{ Reduksi } \\
\hline Arah $x$ & $82.52 \%$ \\
\hline Arah y & $78.08 \%$ \\
\hline
\end{tabular}

Berdasarkan tabel 3 dan gambar grafik sebelumnya, nilai simpangan antar lantai yang menggunakan HDRB lebih kecil dibanding dengan fixed based dikarenakan adanya isolator, maka gaya gempa yang mengenai struktur akan terlebih dahulu bekerja pada isolator kemudian diteruskan ke struktur.

\section{F. Hasil Analisis Pushover}

Hasil analisis pushover yang dilakukan dengan program Analisis Struktur Nonlinier adalah kurva kapasitas (Capacity Curve) skema kelelehan berupa distribusi sendi plastis yang terjadi dan titik kinerja (Performance Point).

$>$ Target Perpindahan (Performance Point)

Dari program analisis struktur didapatkan kurva kapasitas ATC-40, FEMA 356 dan FEMA 440. Selanjutnya performance point didapat dari titik perpotongan antara bilinear force curve dengan capacity curve.

\section{- Metode Spektrum Kapasitas (ATC-40)}

Berikut ini diambil contoh gedung dengan sistem base isolator pada portal arah $\mathrm{x}$, untuk sistem base isolator. Metode ini terdapat secara langsung pada SAP2000 V15, Display - Show Static Pushover Curve - Pilih plot type ATC-40 Capacity Spectrum - Modify/Show Parameters. Data yang diperlukan adalah sebagai berikut :

1. Dari kurva respon spectrum rencana SNI 1726:2012 maka didapat skala factor yaitu 1,22625. Pada demand spectrum definition isikan function respon spectrum yang telah dibuat sebelumnya dana isikan skala faktornya.

2. Parameter damping $=5 \%$

3. Structural behavior : type A (bangunan baru)

Dari kurva yang diperoleh dari analisis struktur, didapat target displacement $(\mathrm{V}, \mathrm{D})$ :

$\mathrm{V}: 1158,144 \mathrm{kN}$ dan $\mathrm{D}: 0,031 \mathrm{~m}$

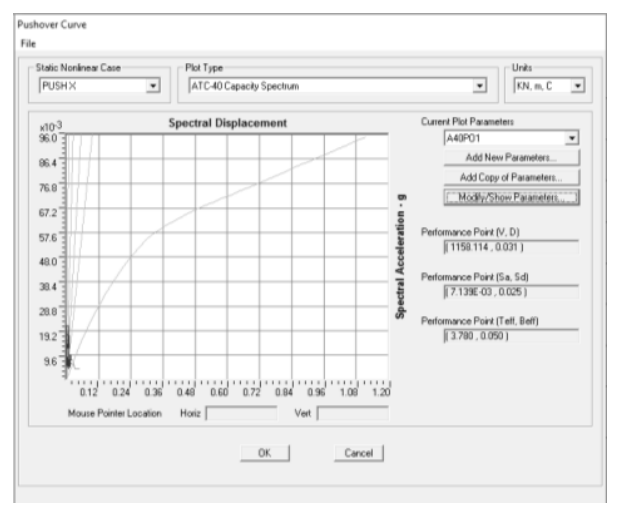

Gambar 10. Kurva Pushover Tipe ATC-40 Capacity Spectrum Arah X. 
Tabel.4.

Distribusi Sendi Plastis Pushover ATC-40 base isolator Arah X

\begin{tabular}{|c|c|c|c|c|c|c|c|c|c|c|c|}
\hline & \multicolumn{2}{|c|}{ Pushover Cane-PTSH X } & \multirow[b]{2}{*}{ AtoB } & \multirow[b]{2}{*}{ Btolo } & \multirow[b]{2}{*}{ Iotols } & \multirow[b]{2}{*}{ LStoCP } & \multirow[b]{2}{*}{ CPtoC } & \multirow[b]{2}{*}{ CtoD } & \multirow[b]{2}{*}{ DtoE } & \multirow[b]{2}{*}{ Beyonde } & \multirow[b]{2}{*}{ Total } \\
\hline & $\begin{array}{c}\text { Displacement } \\
\text { m }\end{array}$ & $\begin{array}{c}\text { Baseforce } \\
\mathrm{KN}\end{array}$ & & & & & & & & & \\
\hline & -0.000025 & & 3888 & & & & & & & & 3888 \\
\hline & 0.026375 & $\begin{array}{l}984.074 \\
1.16938\end{array}$ & 3888 & 10 & & & & & & & 3888 \\
\hline & & & & & & & & & & & 3888 \\
\hline & 0.093606 & 3287.062 & 3658 & 230 & & & & & & & 3888 \\
\hline & 0.121611 & 4033.721.1. & 3574 & 314 & & & & & & & 3888 \\
\hline & & 478821 & 3523 & 365] & & & & & & & 38858 \\
\hline & 0.198918 & 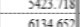 & $\begin{array}{l}3496 \\
349\end{array}$ & 3929 & & & & & & & 3856 \\
\hline & 0 & 024 & 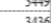 & 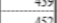 & & & & & & & 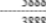 \\
\hline & 0.270811 & 7329.45 & 0 & 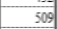 & & & & & & & 3888 \\
\hline
\end{tabular}

Dengan melihat tabel diatas dapat disimpulkan bahwa pada saat terjadi perpindahan maksimum $(\delta \mathrm{T}=0,031 \mathrm{~m})$, struktur termasuk dalam level kinerja gedung B (Operational), yaitu tidak ada kerusakan yang berarti pada struktur dan non structural, gedung masih dapat dipakai secara normal.

- Metode Koefisien Perpindahan (FEMA 356)

Berikut ini diambil contoh gedung dengan sistem base isolator pada portal arah $\mathrm{x}$, untuk sistem base isolator. Metode ini terdapat secara langsung pada program analisis struktur, Display - Show Static Pushover Curve - Pilih plot type FEMA 356 Coefficient Method - Modify/Show Parameters. Data yang diperlukan adalah sebagai berikut :

1. Demand spectrum yang digunakan adalah Defind Function Respon Spectrum yang direncanakan sebelumnya

2. Scale factor $(\mathrm{g} \mathrm{I} / \mathrm{R}=1,226)$.dan batasan periode $\mathrm{Ts}=$ 1,09 yang telah dihitung sebelumnya.

Dari kurva yang diperoleh dari analisis struktur, didapat target displacement $(\mathrm{V}, \mathrm{D})$ :

$\mathrm{V}: 1153,564 \mathrm{kN}$ dan $\mathrm{D}: 0,031 \mathrm{~m}$

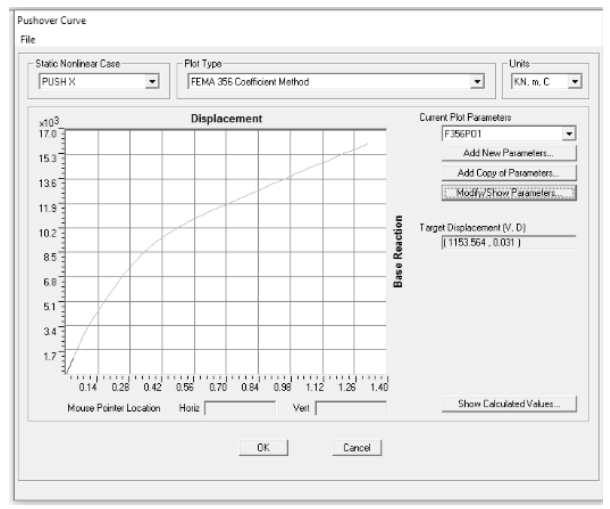

Gambar 11. Kurva Pushover Tipe FEMA 356 Coefficient Method Arah X.

Tabel.5.

Distribusi Sendi Plastis Pushover FEMA 356 base isolator Arah X

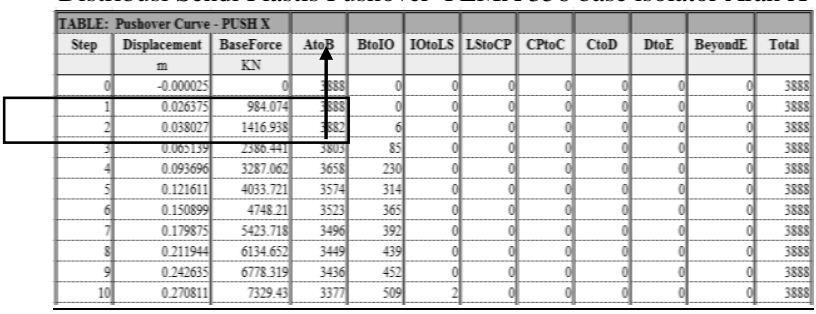

Dengan melihat tabel diatas dapat disimpulkan bahwa pada saat terjadi perpindahan maksimum $\left(\delta_{\mathrm{T}}=0,031 \mathrm{~m}\right)$, struktur termasuk dalam level kinerja gedung B (Operational), yaitu tidak ada kerusakan yang berarti pada struktur dan non struktural, gedung masih dapat dipakai secara normal.

\section{- Metode Koefisien Perpindahan (FEMA 440)}

Berikut ini diambil contoh gedung dengan sistem base isolator pada portal arah $\mathrm{x}$, untuk sistem base isolator. Metode ini terdapat secara langsung pada program analisis struktur, Display - Show Static Pushover Curve - Pilih plot type FEMA 440 Coefficient Method - Modify/Show Parameters. Data yang diperlukan adalah sebagai berikut :

1. Demand spectrum yang digunakan adalah Defind Function Respon Spectrum yang direncanakan sebelumnya

2. Scale factor $(\mathrm{g} I / \mathrm{R}=1,226)$.dan batasan periode $\mathrm{Ts}=$ 1,09 yang telah dihitung sebelumnya.

Dari kurva yang diperoleh dari analisis struktur, didapat target displacement $(\mathrm{V}, \mathrm{D})$ :

$\mathrm{V}: 1174,334 \mathrm{kN}$ dan $\mathrm{D}: 0,031 \mathrm{~m}$

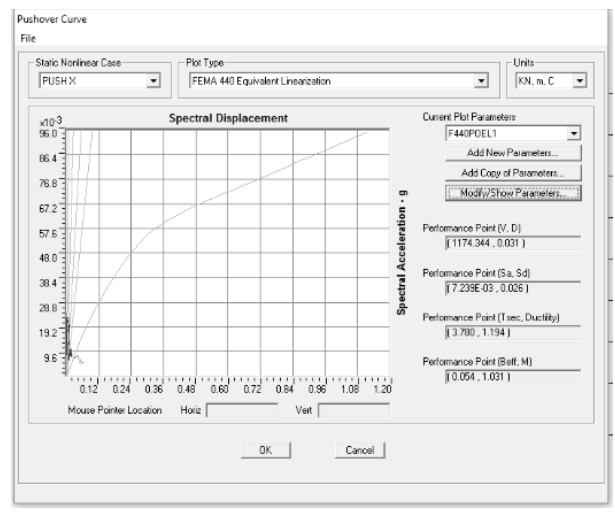

Gambar 12. Kurva Pushover Tipe FEMA 440 Coefficient Method Arah X.

Tabel.6.

Distribusi Sendi Plastis Pushover FEMA 440 base isolator Arah X

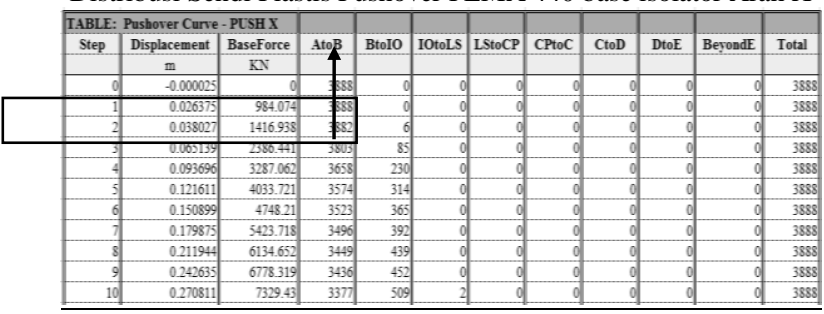

Dengan melihat tabel diatas dapat disimpulkan bahwa pada saat terjadi perpindahan maksimum $\left(\delta_{\mathrm{T}}=0,031 \mathrm{~m}\right)$, struktur termasuk dalam level kinerja gedung B (Operational), yaitu tidak ada kerusakan yang berarti pada struktur dan non struktural, gedung masih dapat dipakai secara normal. 
Tabel 7.

Perbandingan Target Perpindahan (Performance Point) Fixed Base dan $H D R B$

\begin{tabular}{|l|c|c|c|}
\hline \multirow{2}{*}{$\begin{array}{c}\text { Target } \\
\text { Perpindahan }\end{array}$} & \multicolumn{3}{|c|}{ Arah X } \\
\cline { 2 - 3 } & \multicolumn{2}{|c|}{ Base Isolator } & \multirow{2}{*}{$\begin{array}{c}\text { Level } \\
\text { kinerja }\end{array}$} \\
\cline { 2 - 3 } & $\mathrm{V}(\mathrm{kN})$ & $\mathrm{D}(\mathrm{m})$ & $\mathrm{B}$ \\
\hline ATC-40 & 1158.114 & 0.031 & $\mathrm{~B}$ \\
\hline FEMA 356 & 1153.56 & 0.031 & $\mathrm{~B}$ \\
\hline FEMA 440 & 1174.34 & 0.031 & \multicolumn{3}{|c|}{ Arah Y } \\
\hline \multirow{2}{*}{$\begin{array}{c}\text { Target } \\
\text { Perpindahan }\end{array}$} & \multicolumn{2}{|c|}{ Base Isolator } & $\begin{array}{c}\text { Level } \\
\text { kinerja }\end{array}$ \\
\cline { 2 - 3 } & $\mathrm{V}(\mathrm{kN})$ & $\mathrm{D}(\mathrm{m})$ & $\mathrm{B}$ \\
\hline ATC-40 & 1160.519 & 0.032 & $\mathrm{~B}$ \\
\hline FEMA 356 & 1114.505 & 0.03 & $\mathrm{~B}$ \\
\hline FEMA 440 & 1175.508 & 0.032 & \\
\hline
\end{tabular}

\section{KESIMPULAN DAN SARAN}

\section{A. Kesimpulan}

Dari hasil perencanaan dan analisis pada bab-bab sebelumnya, maka dapat disimpulkan sebagai berikut :

1. Perbandingan gaya geser, displacement, simpangan antar lantai, pada gedung yang ditinjau menggunakan base isolator tipe HDRB didaerah gempa kecil dengan fixed base pada daerah gempa besar adalah :

a. Gaya geser yang terjadi pada struktur mengalami reduksi sebanyak $66,59 \%$. Arah x dan $67,30 \%$ arah y.

b. Struktur gedung yang ditinjau menggunakan $H D R B$ memiliki displacement yang lebih besar dari pada struktur gedung fixed based. Pada kasus yang ditinjau, peningkatan displacement gedung yang menggunakan HDRB dibandingkan dengan fixed based terhadap beban gempa yang terjadi adalah :

- Arah x : 66,97\%

- Arah y : 57,53\%

c. Struktur gedung yang ditinjau menggunakan $H D R B$ mampu mengurangi simpangan antar lantai $(\Delta)$ terhadap struktur gedung fixed based. Penurunan simpangan antar lantai pada gedung yang yang ditinjau menggunakan HDRB dibandingkan dengan fixed based terhadap beban gempa yang terjadi adalah
- Arah x : 82,52\%

- Arah y : 78,08\%

d. Berdasarkan hasil perhitungan untuk balok dan kolom secara keseluruhan gaya-gaya dalam pada struktur base isolation mengalami penurunan terhadap struktur fix base.

2. Level kinerja struktur gedung yang ditinjau memakai HDRB dan fixed based menurut ATC-40, FEMA 356 dan FEMA 440 adalah B (Operational), yaitu tidak ada kerusakan yang berarti pada struktur dan non struktural dan gedung masih dapat dipakai secara normal.

\section{B. Saran}

Dari studi ini hanya menganalisis pengaruh penggunaan base isolator jenis HDRB pada struktur gedung beton bertulang menggunakan pushover analysis. Oleh sebab itu disarankan untuk studi selanjutnya, analisis dapat dilakukan dengan membandingkan penggunaan base isolator tipe yang lebih bervariasi, sehingga penerapan prinisip isolator pada struktur gedung dapat diketahui lebih detail.

\section{DAFTAR PUSTAKA}

[1] Y. Lesmana, "Analisis Prilaku Gedung Tinggi Yang Menggunakan Sistem Base Isolation Akibat Beban Gempa Nonlinier Time History Analysis," Institut Teknologi Sepuluh Nopember, 2013.

[2] R. Pratiwi, Eka, Desy, Teruna, Daniel, "Kajian Pengaruh Karakteristik Mekanik Damper Leleh Baja Terhadap Respon Bangunan Akibat Gaya Gempa Dengan Menggunakan Analisis Riwayat Waktu," Univeritas Sumatera Utara, 2013.

[3] B. Nanda, "Aplication Of Tuned Liquid Damper For Controlling Structural Vibration," Institute Of Technologi Rourkela, 2010.

[4] V. Rizcky, "Evaluasi Kinerja Gedung Beton Bertulang Dengan Pushover Analysis Akibat Beban Gempa Padang," Institut Teknologi Sepuluh Nopember, 2013.

[5] W. Pranata, "Kajian Daktilitas Struktur Gedung Beton Bertulang dengan Analisis Riwayat Waktu dan Analisis Beban Dorong," 2008.

[6] R. Pradika, "Perencanaan dan Evaluasi Kinerja Gedung A Rusunawa Gunung Sari Menggunakan Konstruksi Baja Berbasis Konsep Kinerja dengan Metode Pushover Analysis,” 2012.

[7] FEMA-273, NEHRP Guidelines For The Seismic Rehabilitation of Buildings, Report No. FEMA-273. Washington D.C.: Federal Emergency Management Agency, 1996. 